\title{
Kepemimpinan Kepala Madrasah Dalam Upaya Meningkatkan Mutu Pendidikan Dan Kinerja Guru Di MAN 1 Pati
}

\author{
Subaidi \\ Universitas Islam Nahdlatul Ulama Jepara \\ subaidi@unisnu.ac.id
}

\begin{abstract}
This research describe about the leadership of the head madrasah in improving quality of education and performance teacher at MAN 1. This kind of research is field reseach, with the design, case study. The data collection techniques through interviews, observation the questionnaire, and documentation of. As for the analysis of data used in the qualitative study conducted in an interactive and place in a continuous, to completion so that the data is saturated.Activity in, data analysis namely the reduction of, data, presentation of data the withdrawal of conclusions and verification. The research results have to conclude: first an increase in professionalism teacher through direct strategy as the embodiment of a device for teachers, learning efforts to improve the performance of teachers and the evaluation of the learning process as well as training teachers; while coaching professionalism teacher indirectly such as include teacher in various seminars and training, a higher level of magister, including the gfc and mgmp.Both, the development of infrastructures, between pemavingan madrasah, another page the construction of a new building, and renovation of the old building, the manufacture of the fence madrasah, the construction of a mosque and madrasah, and improving the infrastructure of the multi media.Through the effort is expected to the learning process runs smoothly and potential on students. well developed. Meanwhile in the performance of teachers, peneingkatan islamic school head teacher always improve commitment in achieving discipline, motivate teachers work in intense, and the head madrasab be an example.
\end{abstract}

Keywords: Leadership of the head madrasah, the quality of education, teacher performance

Abstrak: Penelitian ini mendeskripsikan tentang kepemimpinan kepala madrasah dalam upaya meningktakan mutu pendidikan dan kinerja guru di MAN 1 Pati. Jenis penelitian ini adalah field reseach, dengan desain studi kasus. Teknik pengumpulan datanya melalui wawancara, observasi, kuesioner, dan dokumentasi. Adapun analisis data yang digunakan dalam penelitian kualitatif dilakukan secara interaktif dan berlangsung secara terus menerus sampai tuntas. Aktivitas dalam analisis data, yaitu reduksi data, penyajian data, penarikan kesimpulan dan verifikasi. Hasil penelitian berkesimpulan: pertama, peningkatan profesionalisme guru melalui strategi langsung seperti perwujudan perangkat pembelajaran bagi guru, upaya peningkatan kinerja guru dan evaluasi proses pembelajaran serta pembinaan guru; sedangkan pembinaan profesionalisme guru secara tidak langsung semisal mengikutsertakan guru dalam berbagai seminar dan pelatihan, studi lanjut tingkat magister, mengikutsertakan KKG dan MGMP. Kedua, pengembangan sarana prasarana, antara lain pemavingan halaman madrasah, pembangunan gedung baru, renovasi gedung lama, pembuatan pagar madrasah, pembangunan Masjid madrasah, dan penyempurnaan ruang multi media. Melalui upaya tersebut diharapkan proses pembelajaran berjalan dengan lancar dan potensi peserta didik berkembang dengan baik. Sedangkan dalam peningkatan kinerja guru, kepala madrasah selalu meningkatkan komitmen guru dalam mewujudkan kedisiplinan, memotivasi kerja guru secara intens, dan kepala madrasah menjadi teladan bagi guru dilingkungan madrasahnya.

Kata Kunci: Kepemimpinan Kepala Madrasah, Mutu Pendidikan, Kinerja Guru 


\section{PENDAHULUAN}

Manusia diciptakan Allah senantiasa untuk menjadi seorang pemimpin, dalam bahasa Arab dikenal dengan khalifah fil ardhi yaitu, pemimpin di bumi. Pada umumnya kepemimpinan dikenal dengan istilah leadership, yaitu, seorang yang mempunyai kemampuan untuk mempengaruhi, mengatur, mengarahkan dan menggerakkan orang lain untuk mencapai suatu tujuan (Maryati, 2016: 165). Dalam dunia pendidikan pemimpin adalah kepala, dalam konteks ini adalah kepala madrasah. Kepala madrasah dalam proses pembelajaran memiliki peran yang sangat strategis serta mempunyai tanggung jawab yang berat untuk meningkatkan kualitas hasil belajar. Mengingat perannya yang sangat besar, keuletannya serta kewibawaannya dalam membuat langkah- langkah baru sebagai jawaban dari kebutuhan masyarakat. Dalam kepemimpinan tidak ada asas yang universal, yang nampak ialah proses kepemimpinan dan pola hubungan antar pemimpinnya. Fungsi utama kepemimpinan terletak dalam jenis khusus dari perwakilan. Kepala madrasah adalah pemimpin tertinggi di unit lembaganya. Gaya kepemimpinannya akan sangat berpengaruh bahkan sangat menentukan kemajuan madrasah tersebut. Oleh karena itu dalam pendidikan modern kepemimpinan kepala madrasah merupakan jabatan strategi dalam mencapai tujuan pendidikan (Indrawari and Hadi, 2019:180).

Menurut Veithzal Rivai (2009) dinyatakan bahwa dalam kajian manajemen, kepemimpinan memiliki peranan penting dalam mencapai tujuan organisasi. Artinya, pemimpin merupakan factor penentu berhasil dan tidaknya suatu organisasi. Untuk mencapai keberhasilan suatu organisasi, tentu saja seorang pemimpin memiliki kualitas yang baik, yaitu mampu mengelola dan menggerakkan organisasi sesuai dengan asas-asas manajemen modern, serta bersedia memberikan kesejahteraan dan kebahagiaan kepada bawahan dan masyarakat luas (Nurhilaliati, 2019:60).

Untuk mewujudkan tujuan-tujuan tersebut kepala madrasah selaku pemimpin mempunyai peranan penting dalam mengkoordinasikan, menggerakkan, dan menyelaraskan sumber daya yang ada sebagai bawahan. Kepemimpinan kepala madrasah harus dapat memotivasi lembaganya untuk merealisasikan visi, misi dan tujuan serta sasaran lembaganya melalui program yang dilaksanakan secara terencana. Kepala madrasah sebagai penanggungjawab pendidikan dan pembelajaran, hendaknya bisa meyakinkan kepada masyarakat bahwa segala sesuatunya telah berjalan dengan baik, termasuk perencanaan dan implementasi kurikulum, penyediaan dan pemanfaatan sumber daya guru, rekrutmen peserta didik, kerjasama madrasah dengan orang tua, serta sosok outcome madrasah yang prospektif. Kepala madrasah yang baik akan bersikap dinamis untuk menyiapkan berbagai macam program pendidikan. Kepala madrasah yang berhasil apabila memahami keberadaan madrasah sebagai 
organisasi yang kompleks, serta mampu melaksanakan peranan dan tanggungjawab untuk memimpin madrasah (Yusnidar, 2014:322-323).

Artinya, sebagai pengelola pendidikan, kepala madrasah bertanggung jawab atas keberhasilan penyelenggaraan kegiatan pendidikan dengan cara melaksanakan administrasi madrasah dan seluruh subtansinya. Disamping itu, kepala madrasah bertanggung jawab atas kualitas sumber daya manusia yang ada agar mereka mampu menjalankan tugas-tugas pendidikan dan pengajaran. Oleh karena itu sebagai pengelola, kepala madrasah memiliki tugas dan tanggung jawab untuk mengembangkan kinerja para personal guru dan tenaga kependidikan lainnya ke arah profesionalisme (Maryati, 2016:165).

Kepala madrasah sebagai pemimpin pendidikan, setidaknya harus memiliki kompetensi dasar manajerial yaitu pertama, keterampilan teknis (technical skill). Keterampilan ini berkaitan dengan pengetahuan, metode dan teknik-teknik tertentu dalam menyelesaikan suatu tugas-tugas tertentu. Dalam tataran implemetatif, keterlibatan seorang pemimpin dalam setiap bentuk technical skill disesuaikan dengan tingkatan pemimpin itu sendiri; kedua, keterampilan manusiawi (buman skill). Keterampilan ini menunjukkan kemampuan seorang pemimpin di dalam bekerja melalui orang lain secara efektif, dan untuk membina kerjasama (Maryati, 2016:167). Dengan kata lain, kepala madrasah yang ideal mampu mengsinergikan kemampuan manajemen dan kemampuan kepemimpinan secara simultan (Baryanto, 2017: 245).

Menurut Igwe dan Odike (2016) bahwa berhasil dan tidaknya sebuah lembaga pendidikan sangat banyak berkaitan erat dengan kualitas kepemimpinan yang dimiliki oleh seorang pimpinan. Oleh karena itu, madrasah sebagai organisasi pendidikan harus dipimpin kepala madrasah yang dapat memfungsikan peran kepemimpinannya dengan baik. Tan (2016) menyatakan bahwa kepala madrasah sebagai pemimpin pendidikan memiliki empat fungsi, yaitu (1) managing the teaching-learning program, (2) designing the organization to emphasize collaborative decision-making processes among different stakeholders, (3) developing an academic school vision and giving directions, (4) understanding and developing teachers (Sonedi, S., Sholihah, T., \& Dihasbi, 2018:67).

Edwaard sallis (2012) dalam buku Total Quality Management In Education mengatakan dalam konsep manajemen mutu pendidikan perlu adanya institusi terbalik dengan menempatkan customer di posisi teratas dalam areal management, baik customer internal maupuan eksternal, lalu guru di nomer dua, setelah itu dipaling bawah adalah leader sebagai pendengar yang baik lalu respon, dan melayani dengan baik. Bukan berarti pada tataran instruksional menjadi terbalik akan tetapi bagaimana seorang pemimpi mampu mengakomodasi keinginan-keinginan dengan baik dan berusaha mengaktualisasikan secara 
berkelanjutan (Server Leadership). Mutu Input dapat dilihat dari beberapa aspek diantaranya situasi dan kondisi baik tidaknya input sumberdaya manusia, seperti pimpinan dan dewan asatid\%. Artinya kualitas buman resource ditentukan oleh keberadaan seorang pemimpin yang keberadaannya mampu menjadi solusi konstruktif dalam segala dimensi problematic kehidupan dalam lingkaran dunia kependidikan dan tampil terdepan bersama pasukan akademiknya yaitu guru untuk mengawal proses sehingga menghasilkan output yang berkualitas, maka disinilah perlu high performance dari semua areal management pendidikan untuk mengaktualisasikan diri dalam sebuah kinerja yang transformative (Abrori, 2018:86).

Dengan demikian, bias nyatakan bahwa tolok ukur utama dalam peningkatan mutu pendidikan adalah komitmen pada perubahan. Jika semua sumber daya guru dan staf madrasah telah memiliki komitmen pada perubahan, pimpinan dapat dengan mudah mendorong dan memotivasi mereka menemukan teknik baru untuk memperbaiki produktivitas, dan kualitas layanan pendidikan (Maryati, 2016:170).

Untuk mewujudkan perbaikan produktivitas, sejalan dengan undangundang Nomor 2 tahun 2003 tentang Sistem Pendidikan Nasional pasal 1, disebutkan bahwa pendidikan adalah usaha sadar dan terencana untuk mewujudkan suasana belajar dan proses pembelajaran agar peserta didik secara aktif mengembangkan potensi dirinya untuk memiliki kekuatan spiritual keagamaan, pengendalian diri, kepribadian, kecerdasan, akhlak mulia serta ketrampilan yang diperlukan dirinya, masyarakat, bangsa dan Negara (Kusen, 2017: 194).

Oleh karena itu, perlu memegangi enam langkah yang harus diupayakandan dilakukan oleh kepala madrasah supaya peningkatan kinerja sumber daya guru dapat dilakukan secara optimal. Salah satunya adalah kepala madrasah harus memiliki komitmen yang tinggi terhadap peningkatan mutu dan kualitas pendidikan madrasah, fokus pada pengembangan kurikulum, menfasilitasi dan mendukung sumber daya guru dalam pengembangan kompetensinya (Hermino, 2016). Upaya yang dapat dilakukan oleh kepala madrasah untuk meningkatkan kinerja sumber daya guru adalah dengan mengarahkan guru supaya mengikuti kegiatan pendidikan dan pelatihan untuk memperbaiki kompetensinya, misalnya, mengikuti seminar atau workshop, pelatihan, dan studi lanjut. Sejalan dengan ini, Mulyasa (2005) menyarankan agar peningkatan kinerja guru dapat dilakukan oleh kepala madrasah dengan melibatkan guru pada kegiatan Musyawarah Guru Mata Pelajaran (MGMP), Musyawarah Guru Pembimbing (MGP), dan Kelompok Kerja Guru (KKG) (Sonedi, S., Sholihah, T., \& Dihasbi, 2018:70). 
MAN 1 Pati Jawa Tengah merupakan salah satu madrasah terbaik di Kabupaten Pati dari sekian madrasah Aliyah negeri dan swasta. Penelitian ini bertujuan untuk mengeksplorasi tentang kepemimpinan kepala madrasah dalam upaya meningkatkan mutu pendidikan dan kinerja guru di MAN I Pati Jawa Tengah. Penelitian ini diharpakn memberi kontribusi, baik secara teotiris maupun praktis terhadap lembaga pendidikan, khususnya madrasah. Dari sisiteorits, dapat menambah pengetahuan tentang peranan kepala madrasah dalam upaya meningkatkan mutu pendidikan dan kinerja sumber daya guru, sedangkan dalam sisi praktis, bisa menambah pengetahuan kepala madrasah dalam melaksanakan perannya sebagai pemimpin pendidikan dalam mencapai mutu pendidikan dan kinerja guru madrasah.

\section{METODE PENELITIAN}

Penelitian ini termasuk jenis fieled research, artinya sebuah langkah penelitian yang dilaksanakan secara langsung di lapangan guna untuk mendapatkan data-data yang dibutuhkan. Desain penelitian ini adalah studi kasus, yaitu penelitian yang fokus pada kasus (fenomena) yang selanjutnya dipahami dan analisis secara mendalam. Kasus atau fenomena dimaksud adalah kepemimpinan kepala madarasah dalam meningkatkan mutu dan kinerja guru di MAN 1 Pati Jawa Tengah, dengan pendekatan ilmu pendidikan dan kepemimpinan. Artinya, peneliti memaparkan berbagai data hasil kajian dan penelitian sesuai dengan kaidah-kaidah ilmu pendidikan dan kepemimpinan.

Sumber data dalam penelitian ini adalah kepala madrasah, guru, dokumen dan para pihak terkait. Teknik pengumpulan data melalui wawancara, observasi, kuesioner, dan dokumentasi. wawancara diajukan kepada informan, yaitu kepala madrasah, guru, komite madrasah, dan siswa dengan menggunakan pedoman wawancara, dan dengan situasi santai guna mendapatkan sebuah gambaran tentang kepemimpinan kepala madarasah dalam meningkatkan mutu dan kinerja guru di MAN 1 Pati Jawa Tengah. Observasi dilakukan dengan melakukan pengamatan dan pencatatan secara sistematis terhadap gejala atau fenomena yang ada pada obyek penelitian. Artinya, secara umum peneliti mengamati situasi yang terjadi di MAN 1 Pati, selanjutnya setelah rekaman hasil analisis awal, diadakan penyempitan pengumpulan data serta melakukan observasi focus Antara lain pengamatan pada kepemimpinan kepala madrasah dalam memotivasi guru dalam peningkatan mutu dan kinerjanya. Kemudian terakhir dilakukan analisa dan pengamatan berulang-ulang, kemudian dilakukan penyempitan lagi dengan melakukan observasi selektif yaitu mengamati obyek yang menjadi focus temuan atas permasalahan yang ada dalam penelitian.

Dokumentasi dilakukan untuk memperoleh data terkait dengan keadaan MAN 1 Pati, semisal jumlah siswa, dan jumlah guru. Hal ini dilakukan untuk 
menganalisa program kerja kepala MAN 1 dan untuk memperoleh data tentang sumber lain yang mendukung adanya data dalam penelitian ini, seperti catatan rapat, catatan hasil supervisi kepala madrasah, dan lain sebagainya. Data yang terkumpul diusahakan kebenaranya dan kemantapannya.

Adapun analisis data yang digunakan dalam penelitian kualitatif yang dilakukan secara interaktif dan berlangsung terus menerus sampai tuntas, sehingga datanya sudah jenuh. Aktivitas analisis data dalam penelitian ini melalui langkah seperti: reduksi data, penyajian data, penarikan kesimpulan dan verifikasi.

\section{HASIL DAN PEMBAHASAN}

\section{Kepemimpinan Kepala Madrasah dalam Meningkatkan Mutu}

Dalam upaya peningkatan mutu di MAN 1 Pati, kepala madrasah berusaha untuk meningkatkan profesionalime guru melalui strategi-strategi, anatara lain: pertama, dilakukan kepala madrasah secara langsung yaitu terkait dengan perangkat pembelajaran guru, meningkatkan kemampuan mengajar guru, mengevaluasi proses pembelajaran yang dilakukan guru, dan mengadakan rapat pembinaan terhadap guru; kedua, dilakukan secara tidak langsung dan melibatkan pihak luar, seperti mendorong mengikuti studi lanjur magister, mengikutsertakan seminar dan pelatihan, mengikutkan kelompok kerja guru (KKG) atau MGMP. Guru-guru yang dalam menunaikan tugas dilaksankan dengan baik dan berprestasi, maka ada pemberian insentif diluar gaji, penghargaan, dan tunjangan yang dapat meningkatkan kinerja mereka, dan juga menempatkan guru berprestasi tersebut pada posisi strategis madrasah.

Dalam hal pembuatan perangkat pembelajaran dalam konteks ini guru haus membuat RPP dan menyiapkan administrasi lainnya, sebagaimana disampaikan Bu Murni (guru, 38 th) menyatakan bahwa:

"guru-guru MAN 1 Pati selalu menyiapkan perangkat pembelajaran berupa RPP, hal ini merupakan program madrasah yang diturunkan oleh waka kurikulum dari kepala madrasah kami. Karena RPP ibarat alat yang utama dalam proses pembelajaran di madrasah, tanpa RPP guru akan kehilangan arah dalam mengendalikan proses pembelajaran di kelas. Disamping itu, guru wajib mengisi administrasi pembelajaran di kelas seperti mengisi jurnal mengajar, mengabsen peserta didik sebelum pembelajaran, membimbing peserta didik berdoa awal pelajaran, bagi guru jam pertama (Wawancara, tanggal 25 Desember 2019, pukul 14.30 WIB). 
Dengan kata lain, guru dituntut memiliki kinerja yang mampu memberikan dan merealisasikan keinginan berbagai pihak terutama masyarakat guna membina peserta didik. Guna untuk meningkatkan kinerja dan kualitas sumber daya guru, pemerintah memberlakukan UU No. 14 Tahun 2005 tentang sertifikasi Guru dan Dosen, namun kinerja guru yang sudah sertifikasi masih belum memuaskan. Salah satu faktor yang mempengaruhi kinerja adalah motivasi berprestasi. Guru dituntut memiliki kinerja yang mampu memberikan dan merealisasikan harapan dan keinginan semua pihak terutama masyarakat umum yang telah mempercayai sekolah dan guru dalam membina anak didik (Miyono, 2017:417). Mengingat, bahwa sebagai seorang pimpinan tertinggi di madrasah, kepala madrasah sangat berpengaruh dan menentukan dalam peningkatan kinerja guru (Sodiah, 2017: 164).

Kepala MAN 1 Pati dalam meningkatkan mutu melalui pengelolaan sarana dan prasarana. Kondisi sarana prasarana dilingkungan MAN 1 Pati cukup memadai, namun jumlahnya belum sebanding dengan jumlah peserta didik. Dalam konteks demikian, kepala madrasah melakukan pengelolaan dan pengembangan sarana prasarana anatara lain: pemavingan halaman madrasah, pembangunan gedung baru, dan renovasi gedung lama, pembuatan pagar madrasah, pembangunan Masjid madrasah, dan penyempurnaan sarana prasarana ruang multi media. Melalui upaya tersebut diharapkan proses pembelajaran berjalan dengan lancar dan potensi pada peserta didik berkembang dengan baik.

Hal tersebut sejalan dengan fungsi kepemimpinan yang memiliki dua dimensi, yaitu: Pertama, dimensi yang berkenaan dengan tingkat kemampuan mengarahkan (direction) dalam tindakan atau aktivitas pemimpin. Kedua, dimensi yang berkenaan dengan tingkat dukungan (support) atau keterlibatan orang-orang yang dipimpin dalam melaksanakan tugas-tugas pokok kelompok atau organisasi (Maryati, 2016:169). Sebagaimana disampaikan oleh Bp. Suhono bahwa:

"pak kepala madrasah dalam peneglolaan sarana prasarana di madrasah ini selalu melibatkan komite madrasah. Keperuntukannya untuk berbagai kegiatan, seperti pemavingan, pembuatan pagar, pembangunan masjid, dan pembangunan gedung. Ia mempercayakan pelaksanaan kegiatan pembangunan tersebut kepada komite madrasah. Dengan dibangunnya sarana prasarana yang ada agar proses pembelajaran di madrasah nyaman dan lancar, dan citra madrasah di mata masyarakat Pati dan sekitarnya semakin baik ....(Wawancara, tanggal 25 Desember 2019 pukul 14.35 WIB).

Pengadaan dan pengelolaan mutu sarana prasarana madrasah berupa pavingisasi akan meningkatkan rasa nyaman dan aman dilingkungan MAN 1 
Pati, tertama bila musim hujan tiba. Peserta didik tidak perlu lagi merasa was was lagi terkait dengan berbagai kegiatan diluar kelas yang harus memanfaatkan halam madrasah.

Terkait dengan pembangunan pagar madrasah, akan berdampak dengan keamanan kendaraan dan sepeda semua peserta didik. Mereka tidak terganggu pikrannya ketika ada di kelas terkait dengan kendaraan dan sepeda mereka, karena sudah merasa terpagari dengan baik dan aman.

Karena pendidikan merupakan bagian dari pelayanan jasa yang dilaksanakan oleh lembaga penyelenggara pendidikan atau satuan pendidikan bagi dan untuk kepentingan masyarakat. Pendidikan seharusnya diorientasikan pada peningkatan mutu pelayanan agar tercipta proses pendidikan yang menyenangkan dan memuaskan sehingga mendorong peserta didik untuk semangat belajar yang pada akhirnya diharapkan bisa menghasilkan output pendidikan yang bermutu (Suarga, 2017:23).

Adanya pembangunan masjid madrasah bertujuan untuk menciptakan iklim relegius dilingkungan MAN 1 Pati. Hal ini telah mendapat perhatian serius oleh kepala madrasah, sebagaimana telah diungkapkan dalam wawancara sebagai berikut:

“.....masjid yang direncanakan untuk mendorong anak-anak dan dewan guru agar rajin beribadah, seperti shalat dhuha, sahalat jama'ah pada saat shalat dhuhur, sampai dengan saat shalat ashar, karena madrasah telah memberlakukan boording bagi anak-anak yang rumah mereka jauh dari madrasah. Kegiatan pembangunan ini dananya dari swadaya baik dari kesadaran para guru dalam bersedekah, wali murid dan para aghniya' yang peduli dengan keberadaan masjid madrasah... (Wawancara, tanggal 25 desember 2019, pukul 14.15 WIB).

Dari hasil wawaancara di atas dapat diketahui bahwa kepala MAN 1 Pati berusaha untuk mewujudkan sarana prasarana secara maksimal, dimana sarana prasarana tersebut secara langsung berhubungan dengan kegiatan proses pembelajaran yang ada di madrasah. Hal ini merupakan bagian dari layanan madrasah dilingkungan MAN 1 Pati, karena layanan merupakan sebuah proses pemberian jasa (servicedelivery) dari produsen kepada pelanggan (costumer). Layanan yang bermutu dan berkualitas adalah layanan yang dapat memenuhi atau bahkan melebihi kebutuhan yang diharapkan oleh pengguna jasa layanan (Ridwan, 2013:5). Menurut Kotler kepuasan adalah hasil yang dirasakan oleh konsumen yang mengalami kinerja sebuah lembaga yang sesuai dengan harapannya (Suarga, 2017:24). 


\section{Kepemimpinan Kepala Madrasah dalam Meningkatkan Kinerja Guru}

a. Kepemiminan kepala madrasah dalam meningkatkan komitmen guru di MAN 1 Pati Jawa Tengah

Sebagaiman wawancara dengan kepala madrasah dan guru di MAN 1 Pati bahwa untuk mencapai komitmen secara efektif, apa yang dilakukan oleh kepala madrasah terhadap guru dilingkungan MAN 1 Pati sudah benar dan tepat. Sebagaimana diungkapkan Bp. Agus Rofiq (guru, 35 th):

"kepala madrasah kami sangat disiplin, masuk tepat waktu, jam 07.00 WIB sudah berada di madrasah, memberi contoh kepada para guru sebagai binaannya, terutama jika hari upacara, baik upacara bendera rutin maupun saat upacara hari-hari besar nasional dan Islam, ia rawuh lebih gasik" (Wawancara, tanggal 12 Desember 2019, pukul 13.15 WIB).

Artinya, disiplin waktu merupakan salah satu kunci keberhasilan komitmen. Kepala madrasah dalam melakukan kedisplinan sudah sangat tepat dalam meningkatkan kinerja guru. Hal demikian menjadi tuntutan yang sangat penting untuk dimiliki dalam upaya menunjang dan meningkatkan kinerja sumber daya guru di MAN 1 Pati Jawa Tengah dan disisi lain memberikan keteladanan bagi siswa bahwa disiplin amat penting bagi siapa saja bila berkeinginan untuk sukses dalam meraih sebuah cita-cita. Hal tersebut sejalan dengan yang diungkapkan Mulyasa (2007) bahwa kepribadian kepala madrasah sebagai leader akan tercermin sifat-sifat, seperti jujur; percaya diri; tanggung jawab; berani mengambil resiko dan keputusan; berjiwa besar; emosi yang stabil dan; teladan (Bakri, 2016:141).

Kepala MAN 1 Pati juga mendorong dan memotivasi sumber daya guru dalam pelaksanaan program pembelajaran, hal demikian dapat diamati adanya rencana program pembelajaran (RPP) yang telah dilakukan guru dilingkungan madrasah tersebut. Sebagaimana Ibu Murni (guru, 38 th) bahwa:

"guru wajib menyusun RPP, itulah motivasi kepala madrasah kami. RPP ibarat alat yang utama dalam bekerja, tanpa RPP guru akan kehilangan arah, ia mau jalan kemana. Komitmen kepala MAN 1 Pati dalam menyusun RPP didahului dengan mendatangkan pakar, agar mereka mampu menyusun secara baik dan benar (Wawancara, tanggal 12 Desember 2019, pukul 13.30 WIB).

Bisa dipahami bahwa, kepala madrasah berkomitmen disiplin dalam mewujudkan program kemadrasahan, salah satunya adalah adanya rencana program pembelajaran (RPP) yang tidak bisa ditawar oleh para pendidik dilingkungan MAN 1 Pati. Hal ini dilakukan secara bersama-sama guna 
mewujudkan kondisi humanis untuk mencapai dunia pendidikan yang kondusif di MAN 1 Pati.

Bisa dipahami bahwa, kepala madrasah berkomitmen dalam meningkatkan kinerja guru dan kedisiplinan dalam mewujudkan program kemadrasahan, salah satunya adalah adanya rencana program pembelajaran (RPP) yang tidak bisa ditawar oleh para pendidik dilingkungan MAN 1 Pati. Hal ini dilakukan secara bersama-sama guna mewujudkan kondisi humanis untuk mencapai dunia pendidikan yang kondusif di MAN 1 Pati.

Artinya, tugas-tugas utama para guru yang direalisasikan dalam proses pembelajaran serta tugas-tugas guru dalam kelembagaan marupakan bentuk budaya dan kinerja guru. Apabila kinerja guru meningkat, maka berpengaruh pada peningkatan mutu dan kualitas luaran atau outputnya. Guru yang kompeten akan mampu menciptakan suasana belajar secara optimal. Kompetensi yang dimiliki guru sangat menentukan berhasil tidaknya proses pembelajaran yang dilaksanakan, dan akan berpengaruh pada capaian kinerja madrasah (Miyono, 2017:416).

b. Kepemimpinan kepala madrasah dalam meningkatkan motivasi kerja guru di MAN 1 Pati

Dalam membangun peningkatan motivasi kerja guru di MAN 1 Pati, kepala madrasah menggunakan perpaduan pendekatan yaitu kekeluargaan dan profesionalisme kerja. Segaimana disampaikan Bp. Suprayogo (guru, 38 th):

"pak kepala itu sering meluangkan waktu bertemu dengan para guru pada waktu jam istirahat baik istirahat pertama maupun kedua. Ia selalu membuka komunikasi dengan semua dewan guru, terkait dengan hal-hal yang ada hubungannya dengan berbagai hal, seperti anak yang sering tidak masuk, sering mbolos, bahkan sampai anak yang sering memperoleh renking di kelas, dan kejuaraan lainnya. Dalam suasana santai dan rileks kepala madrasah memberikan arahan dalam menyelesaikan berbagai problem yang dialami oleh guru, jadi tidak perlu menunggu rapat dinas madrasah atau rapat guru" (Wawancara, tanggal 12 Desember 2019, Pukul 13. 45 WIB).

Bisa dipahami bahwa kepala MAN 1 Pati membangun motivasi dan ambisi kerja dilingkungan lembaga yang ia pimpin dengan komunikasi secara intensif baik secara kedinasan maupun non kedinasan. Inilah yang dimaksud perpaduan dua pendekatan yaitu pendekatan kekeluargaan dan profesionalisme. Konsep demikian diawali dengan membuka komunikasi dengan seluruh guru dilingkungan MAN 1 Pati, berbagai saran dan keluhan disampaikan guru, dan oleh kepala madrasah boleh menyampaikan diluar lingkungan madrasah. 
Langkah demikian dimaksudkan untuk memetakan seluruh harapan dan keinginan bahkan sampai hambatan yang dialami oleh guru di MAN 1 Pati dalam menunaikan tugas.

Hal tersebut sejalan dengan pernyataan Samsudi (2006) bahwa kepemimpinan merupakan kemampuan meyakinkan dan menggerakkan orang lain agar mau bekerja di bawah kepemimpinanannya sebagi suatu tim untuk mencapai suatu tujuan (Bakri, 2016:143). Dengan kata lain, pemimpin yang efektif akan mampu menciptakan budaya kerjasama tim secara baik diantara anggota organisasi madrasah, melakukan komunikasi yang efektif dengan para bawahan, serta menciptakan lingkungan kerja yang baik pula. Dengan terciptanya kerjasama yang baik, maka seluruh pekerjaan akan diselesaikan dengan tepat waktu, tujuan yang diinginkan bisa tercapai (Suarga, 2017:33).

Hal demikian juga sejalan dengan Muflihin (2018) yang menyatakan bahwa sifat-sifat yang harus dimiliki oleh seorang pemimpin itu, yaitu: (1) mempunyai dorongan yang kuat untuk bertanggung jawab atas tugas yang dipercayakan kepadanya; (2) teguh mempertahankan pekerjaan untuk memenuhi tujuan; (3) mempunyai dorongan yang kuat untuk menguji beragam inisiatifnya dalam situasi sosial; (4) percaya diri dan mempunyai perhatian yang penuh terhadap identitas pribadi anggota; (5) dapat menerima berbagai keputusan dan tindakan yang bahkan tidak menguntungkan dirinya; (6) dapat membawa dan menyerap semua hasrat dan keinginan anggota; (7) dapat bersikap toleran terhadap kegagalan dan frustasi; (8) mampu memengaruhi perilaku anggota, beradaptasi dengan struktur sosial, serta sistem interaksi (Nurhilaliati, 2019:62).

c. Kepemimpinan Kepala Madrasah dalam meningkatkan disiplin guru di MAN 1 Pati

Sebagaimana hasil wawancara dengan Bp. Agus Rofiq (guru, 35 th):

"Pak kepala madrasah memberi contoh kedisiplinan rawub (hadir) lebih pagi sebelum para guru dan karyawan madrasah hadir di madrasah. Karena di MAN 1 Pati mencanangkan motto "Datang lebih awal, pulang terlambat". Berangkat dati komitmen ini Pak kepala madrasah memberikan keteladanan kepada bawahannya terkait dengan kedisiplinan” (Wawancara, tanggal 22 Desember 2019, Pukul 12. 30 WIB).

Dapat dipahami bahwa salah satu kedisiplinan yang dapat diteladani dari kepala madrasah adalah kehadirannya tepat waktu sebelum para guru dilingkungan MAN 1 Pati ini hadir di madrasah. Dengan menunjukkan kedisiplinan yang tinggi kepada guru-guru bianaan, tentu guru-guru tersebut akan dating di madrasah tepat waktu, karena ada rasa ewnh pekewnh dengan 
pimpinannya. Hal tersebut juga bisa diartikan bahwa kepala madrasah memberikan beberapa strategi dalam meningkatkan motivasi guru, antara lain: mengimplementasikan gerakan kedisiplinan dalam menjalankan pekerjaan; memberikan keteladanan kepada guru dalam kedisiplinan; membentuk tim pengawasan kedisiplinan.

Sejalan dengan penjelasan bahwa pemimpin yang menunjukkan pengaruh yang baik dan memberikan nilai positif bagiorganisasi dan parapengikutnya, akan mampumenjadi teladan bagi yang dipimpinnya. Keteladanan seorang pemimpin ditunjukkan melalui sikap dalam memberikan inspirasi, membimbing dan memotivasi para bawahan, memiliki kemampuan luas, kreatif, visioner, bekerja secara jujur dan ikhlas, serta memiliki perhatian dan kepedulian. Pemimpin harus menjadi panutan, dan bisa diikuti kepribadiannya bagi orang-orang yang dipimpinnya (Suarga, 2017:31).

\section{KESIMPULAN}

Berdasarkan uraian di atas dapat disimpulkan bawa kepemimpinan kepala madrasah dalam meningktakan mutu dan kinerja guru di MAN 1 Pati anatara lain: Pertama, peningkatan profesionalisme guru melalui strategi langsung seperti perwujudan perangkat pembelajaran bagi guru, upaya peningkatan kinerja guru dan evaluasi proses pembelajaran serta pembinaan guru; sedangkan pembinaan profesionalisme guru secara tidak langsung semisal mengikutsertakan guru dalam berbagai seminar dan pelatihan, studi lanjut tingkat magister, mengikutsertakan KKG dan MGMP. Kedua, pengembangan sarana prasarana, anatara lain pemavingan halaman madrasah, pembangunan gedung baru, dan renovasi gedung lama, pembuatan pagar madrasah, pembangunan Masjid madrasah, dan penyempurnaan sarana prasarana ruang multi media. Melalui upaya tersebut diharapkan proses pembelajaran berjalan dengan lancar dan potensi pada peserta didik berkembang dengan baik. Sedangkan dalam peneingkatan kinerja guru, kepala madrasah selalu meningkatkan komitmen guru dalam mewujudkan kedisiplinan, memotivasi kerja guru secara intens, dan kepala madrasah menjadi teladan bagi guru dilingkungan madrasahnya.

\section{UCAPAN TERIMA KASIH}

Ucapan terima kasih disampaikan kepada pihak yang telah membantu terselenggaranya penelitian ini, antara lain kepada pihak madrasah (kepala madrasah, guru, tenaga kependidikan dan siswa) dilingkungan MAN 1 Pati yang telah membantu memberikan data melalui wawancara dan kuesioner yang menjadi sampel dalam kajian ini. Demikian pula kepada Direktur Program Pascasarjana UNISNU Jepara yang telah memberi ijin dalam penelitian ini. 
Penulis juga mengucapkan banyak terima kasih kepada redaksi jurnal Tadbir yang berkenan memberikan koreksi dan masukannya sehingga artikel ini bisa dipublikasikan di Tadbir: Jurnal Studi Manajemen Pendidikan.

\section{REFERENSI}

Abrori, H. (2018) 'Revitalisasi Kepemimpinan Untuk Meningkatkan Mutu Pendidikan Madrasah', Jurnal Manajemen Pendidikan Islam, 3(2).

Bakri, M. (2016) 'Kompetensi Kepala Sekolah Sebagai Leader dalam Meningkatkan Mutu Pendidikan Agama Islam. (Studi di Sekolah dasar Al-Ma'arif 02 Singosari Malang)', Islamidina. Jurnal Pascasarjana Agama Islam Swasta, 1(2).

Baryanto (2017) 'Manajemen Kepala Madrasah Dalam Meningkatkan Kualitas Pendidikan Di MTS Nurul Kamal Kabupaten Rejang Lebong, TADBIR: Jurnal Studi manajemen Pendidikan, 1(02).

Indrawari, K. and Hadi, A. (2019) 'Gaya Kepemimpinan Kepala Yayasan Dalam Meningkatkan Kinerja Guru TK Nur Iman Palembang', Tadbir: Jurnal Studi Manajemen Pendidikan, 3(2), p. 179. doi: 10.29240/jsmp.v3i2.1063.

Kusen (2017) 'Peningkatan Mutu Pendidikan Agama Islam Berbasis Kontekstual', TADBIR : Jurnal Studi Manajemen Pendidikan, 1(02).

Maryati (2016) 'Pola Kepemimpinan Kepala Madrasah dalam Meningkatkan Mutu Pendidikan di MTs Nurul Qur'an Tegalweropucakwangi Pati', QUALITY, 4(1), pp. 163-181.

Miyono, N. (2017) 'Determinan Budaya Kerja Guru Madrasah Tsanawiyah di Kabupaten Demak', EDUKASI: Jurnal Penelitian Pendidikan Agama Dan Keagamaan, 15(3), pp. 405-420.

Nurhilaliati, N. (2019) 'Kualitas Kepemimpinan Kepala Madrasah Perempuan di Lingkungan Pondok Pesantren', EDUKASI: Jurnal Penelitian Pendidikan Agama Dan Keagamaan, 17(1), pp. 57-69.

Sodiah (2017) 'Etika Kerja Kepala Sekolah Dalam Meningkatkan Kinerja Guru', TADBIR : Jurnal Studi Manajemen Pendidikan, 1(02).

Sonedi, S., Sholihah, T., \& Dihasbi, D. (2018) 'Peran Kepemimpinan Kepala Sekolah dalam Meningkatkan Kinerja Guru', Anterior Jurnal, 18(1), pp. 13-22.

Suarga (2017) 'Efektivitas Penerapan Prinsip-Prinsip Kepemimpinan Kepala Sekolah Terhadap Peningkatan Mutu Layanan Administrasi Pendidikan', Jurnal Idarah, 1(1). 
174 | Tadbir : Jurnal Studi Manajemen Pendidikan, Vol. 4, No. 2, 2020

Yusnidar, Y. (2014) 'Kepemimpinan Kepala Madrasah Dalam Meningkatkan Kinerja Guru Pada Man Model Banda Aceh', Jurnal Ilmiah Didaktika, 14(2), pp. 320-349. 